\title{
Perancangan Program Administrasi Pembayaran SPP, UTS dan UAS Pada MA Al-Marzukiyah Jakarta
}

\author{
Yamin Nuryamin, Eko Setia Budi \\ STMIK Nusa Mandiri, Jakarta, Indonesia \\ J1. Damai No.8 Warung Jati Barat (Margasatwa), Jakarta Selatan, Indonesia \\ Email: ${ }^{1}$ yamin.yny@bsi.ac.id, ${ }^{2}$ eko.etb@ nusamandiri.ac.id
}

\begin{abstract}
Abstrak-MA. Al-Marzukiyah merupakan sekolah Islam yang sejajar dengan Sekolah Menengah Atas (SMA). Dalam proses transaksi pembayaran SPP, UTS dan UAS, banyak sekali data yang terlibat dimana semua data tersebut masih dikerjakan secara manual. Adapun maksud dari penelitian tugas akhir ini adalah untuk membuat sebuah rancangan program pembayaran berbasis visual basic yang akan diterapkan pada MA. Al-Marzukiyah sebagai alat pengolahan data serta mengubah sistem manual ke sistem komputerisasi, dimana alat yang digunakan untuk merancang aplikasi yaitu ERD (Entity Relationship Diagram), LRS (Logical Relational Diagram), dan Data Alur Diagram (Flow Chart). Aplikasi ini dibuat dengan menggunakan beberapa software yaitu Microsoft Visual Basic 6.0 sebagai software editor, Mocrosoft Access 2013 sebagai database dan IcoFx 2 sebagai symbol editor. Aplikasi berbasis visual basic yang dibuat ini mempunyai kelebihan dalam kecepatan dan ketepatan dalam proses pengolahan data transaksi pembayaran, sehingga dapat mempermudah petugas dalam pengolahan data. Aplikasi ini juga mempermudah kinerja dalam proses pelaporan data transaksi.
\end{abstract}

Kata Kunci: Program, Aplikasi, Visual Basic, Administrasi, Pembayaran SPP, UTS dan UAS, MA. Al-Marzukiyah.

Abstract-MA. Al-Marzukiyah is an Islamic high school parallel to senior high school. In the process of payment contributions education development, middle exam and final exam, a lot of data involved where all the data still be constructed manually. The research duty end of this is to make a design of the program payment administration based visual basic to be applied to MA. AlMarzukiyah as a means of data processing and change manual system to a computerized system, where an instrument used to design application named ERD (Entity Relationship Diagram), LRS (Logical Relation Diagram) and Flowchart. This application made by using several software that is Microsoft Visual Basic 6.0 as software editor, Microsoft Access 2013 as a database and IcoFx 2 as symbol editor. Based program visual basic made this a strength in speed and the accuracy of in the process of data processing payment transaction, to simplify officers in data processing. This program also simplify performance in the process of reporting transaction data.

Keywords: Program, Application, Visual Basic 6.0, Administration, The Payment Contributions Education Development, Middle Exam and Final Exam, MA. Al-Marzukiyah

\section{PENDAHULUAN}

Tak dapat dipungkiri jika kemajuan teknologi masa kini berkembang sangat pesat. Hal ini dapat dibuktikan dengan banyaknya inovasi-inovasi yang telah dibuat di dunia ini. Dari hingga yang sederhana, hingga yang menghebohkan dunia. Teknologi adalah keseluruhan sarana untuk menyediakan barang-barang yang diperlukan bagi kelangsungan, dan kenyamanan hidup manusia. Perkembangan teknologi telah memperkecil hambatan fisik terhadap komunikasi dan memungkinkan manusia untuk berinteraksi secara bebas dalam skala global. Teknologi juga dapat diartikan sebagai alat bantu fisik dan non fisik yang digunakan oleh manusia dalam memenuhi kebutuhan dan pencapaian tujuan dalam hidupnya.

Salah satu contoh hasil perkembangan teknologi adalah komputer. Penggunaan komputer untuk menyusun, membuat program-program yang dapat membantu dan menyederhanakan kegiatan instansi-instansi dalam pemerintah juga semakin luas dan kompleks. Hampir seluruh aktifitas sehari-hari manusia dipengaruhi oleh komputer, baik dalam hal penyampaian informasi seperti mengirim email, melihat berita, mempersiapkan laporan sampai pembuatan program dan lain sebagainya.

Dengan latar belakang demikian, penulis ingin merancang suatu program yang bertujuan mempermudah transaksi pembayaran SPP, UTS dan UAS di MA. Al-Marzukiyah. Karena saat ini sistem pembayaran SPP, UTS dan UAS di sekolah tersebut, masih belum terkomputerisasi, sehingga untuk rekap laporan keuangan masih belum terorganisir dengan baik. Dengan sistem komputerisasi mampu menyajikan informasi dengan teliti dan tepat, sehingga sistem pembayaran SPP, UTS dan UAS di MA. Al-Marzukiyah, diharapkan dapat disajikan lebih efisien.

\section{METODE PENELITIAN}

Metode penelitian adalah salah satu cara atau teknik yang sistematik untuk mengerjakan atau menyelesaikan sesuatu untuk mendapatkan informasi yang benar-benar dimengerti atau dipahami. Dalam penulisan laporan pembuatan program ini, penulis menggunakan 2 (dua) metode, yakni: 
Metode yang digunakan pada pengembangan perangkat lunak ini menggunakan model waterfall. Waterfall terbagi menjadi 3 (tiga) tahapan, yaitu:

1. Analisis Kebutuhan

Analisis atau analisa ini merupakan tahap awal yang dilakukan oleh peneliti dalam mengembangkan sistem. Dalam analisis ini harus mendapatkan beberapa hal yang dianggap menunjang penelitian yang dilakukan, seperti mencari permasalahan yang ada, mengumpulkan data, wawancara dan lain-lain.

2. Perancangan Sistem dan Perangkat Lunak

Proses perancangan sistem ini difokuskan pada empat atribut, yaitu struktur data, representasi antarmuka, arsitektur perangkat lunak, dan interaksi antar objek di dalam sekolah.

3. Implementasi

Pada tahap ini, perancangan perangkat lunak direalisasikan sebagai serangkaian program atau unit program.

\subsection{Teknik Pengumpulan Data}

Untuk lebih jelas dalam penyusunan laporan ini, penulis menggunakan metode-metode yang sesuai dengan masalah tersebut, adapun metode yang digunakan, yaitu:

1. Metode Observasi

Penulis memperoleh data-data dengan mengamati langsung dan mencatat hal-hal yang berhubungan dengan permasalahan secara lengkap dan sistematis.

2. Metode Wawancara

Penulis melakukan wawancara ke bagian keuangan yang menangani langsung pembayaran SPP, UTS dan UAS. Wawancara ini dilakukan dengan proses tanya jawab untuk mengetahui informasi mengenai sistem pembayaran spp sekolah.

3. Metode Literatur

Metode yang berfungsi sebagai pedoman dan landasan teori data-data observasi dan tanya jawab yaitu dengan cara studi perpustakaan dan buku-buku yang ada kaitannya dengan hal yang akan dibahas.

\section{HASIL DAN PEMBAHASAN}

Pada dasarnya setiap sistem memiliki kelebihan dan kekurangan dan tidak semua sistem itu buruk, akan tetapi sistem yang telah terkomputerisasi jauh lebih baik dibandingkan dengan sistem yang manual. Sistem pembayaran SPP, UTS dan UAS selama ini masih menggunakan sistem manual. Pengelolaan data seperti ini akan mudah rusak dan hilang, baik karena faktor kelalaian manusia (human error) atau kerusakan sistem.

\subsection{Entity Relationship Diagram (ERD) dan Logica Relation Structure (LRS)}

Perancangan basis data menghasilkan pemetaan tabel-tabel yang digambarkan dengan Entity Relationship Diagram (ERD) dan Logical Relation Structure (LRS).

\section{a. Entity Relationship Diagram (ERD)}

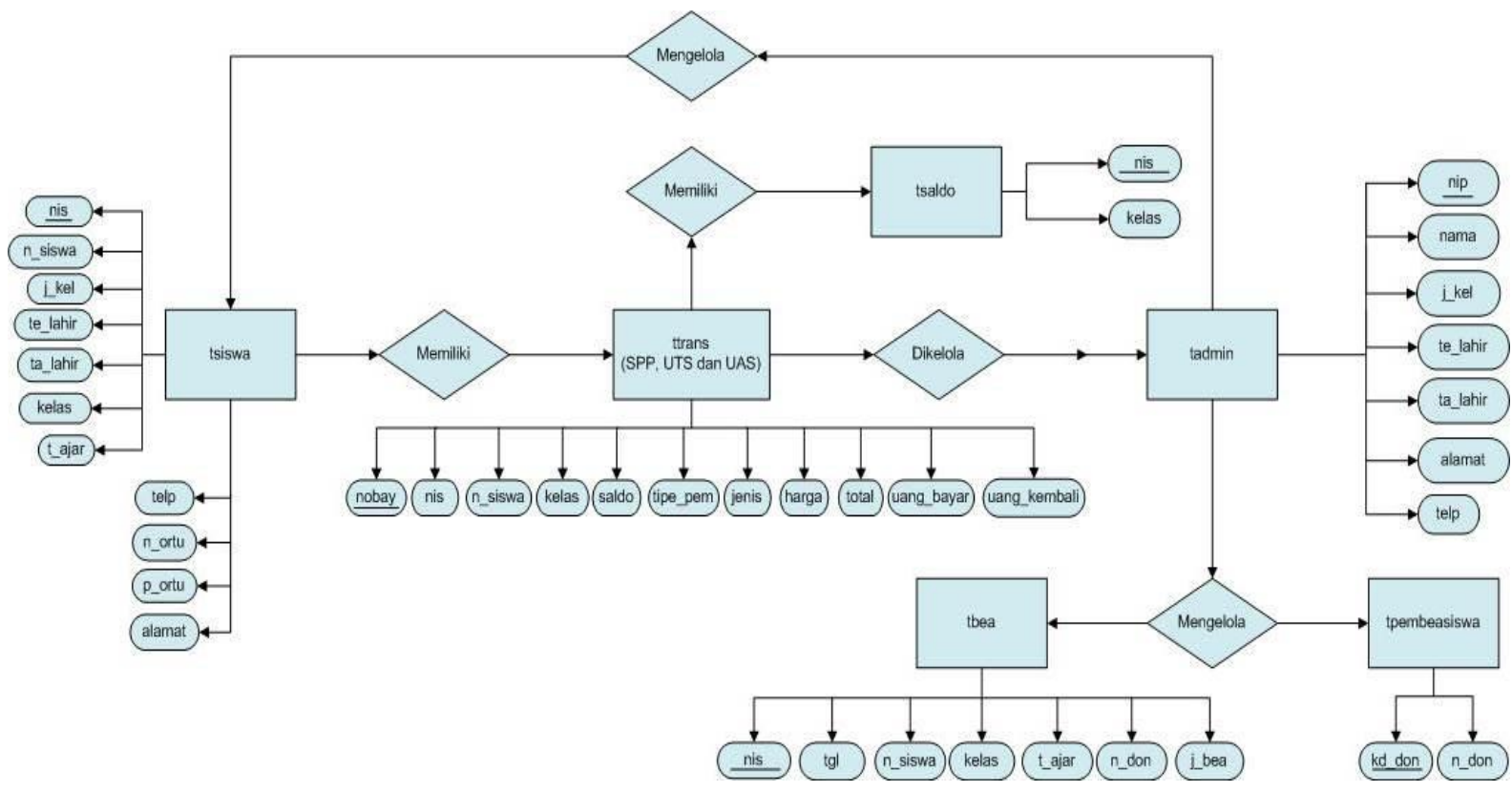

Gambar 1. Entity Relationship Diagram Pembayaran Administrasi 


\section{b. Logical Relation Structure (LRS)}

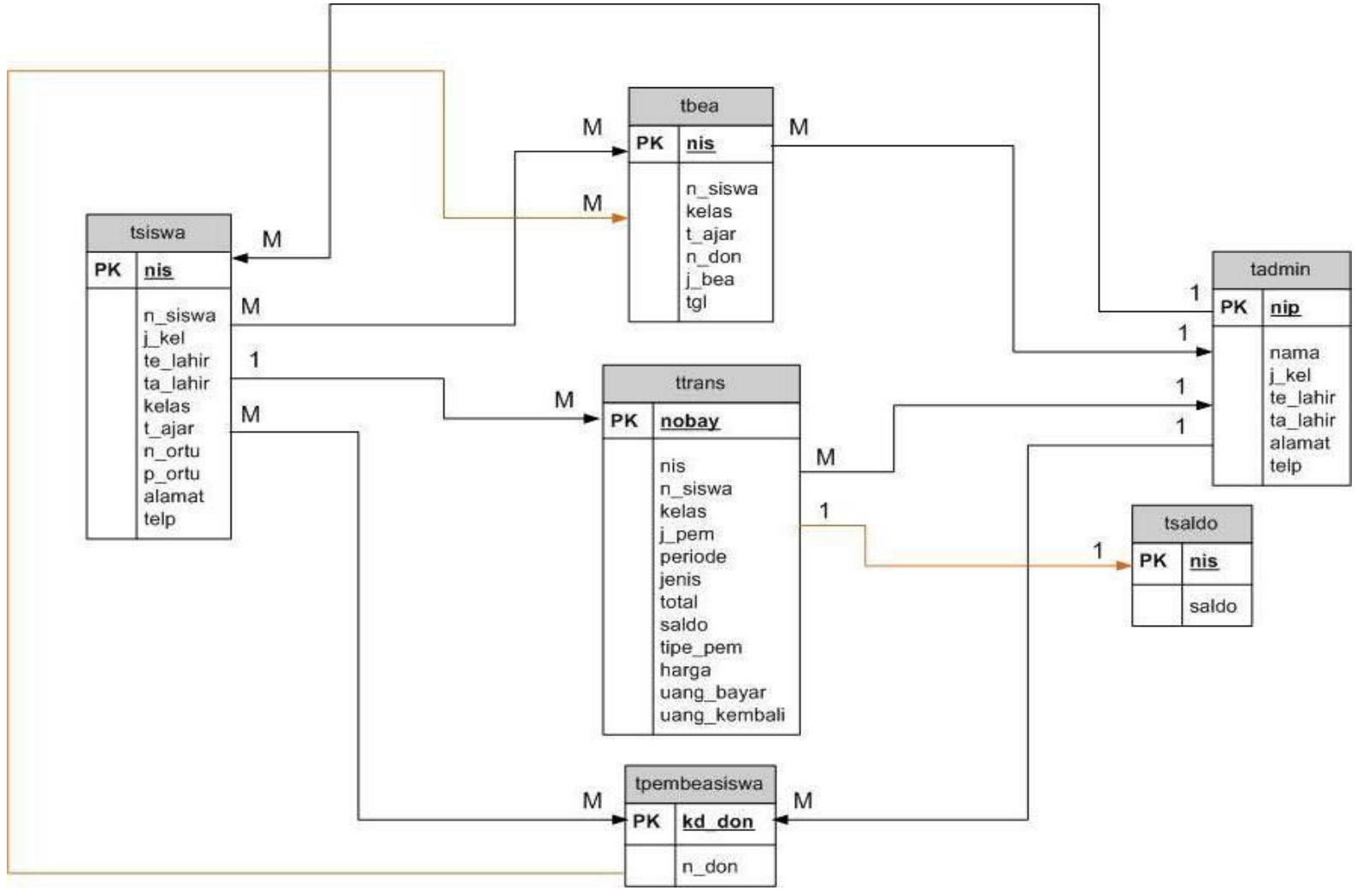

Gambar 2. Logical Relation Structure Pembayaran Administrasi

\subsection{Spesifikasi Program}

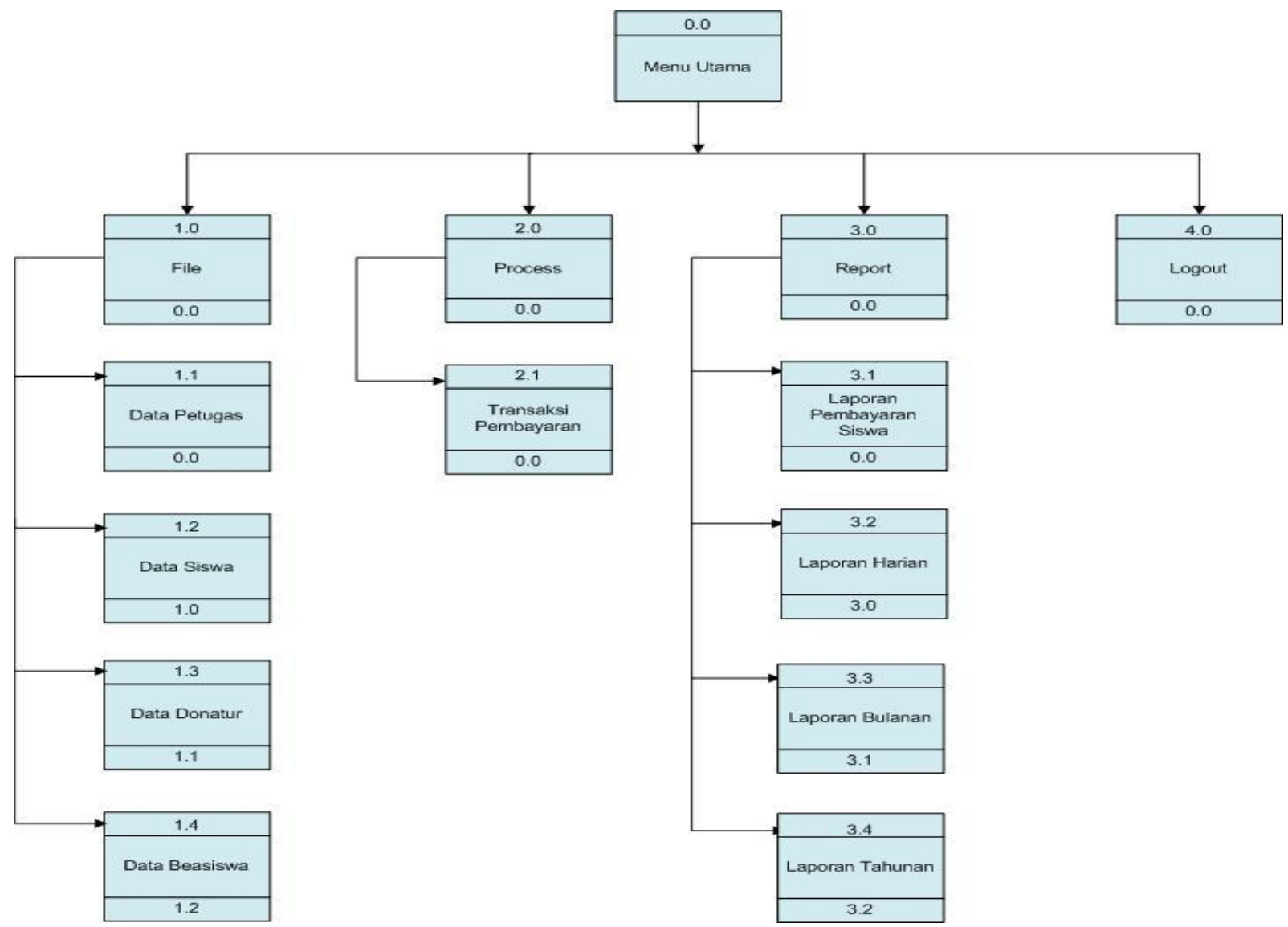

Gambar 3. Diagram Hierarchy Input Process Output 
JSON Volume 1, Nomor 2, Januari 2020

e-ISSN 2685-998X

DOI 10.30865/json.v1i2.1852

\subsection{Implementasi Program}

\section{a. Form Data Petugas}

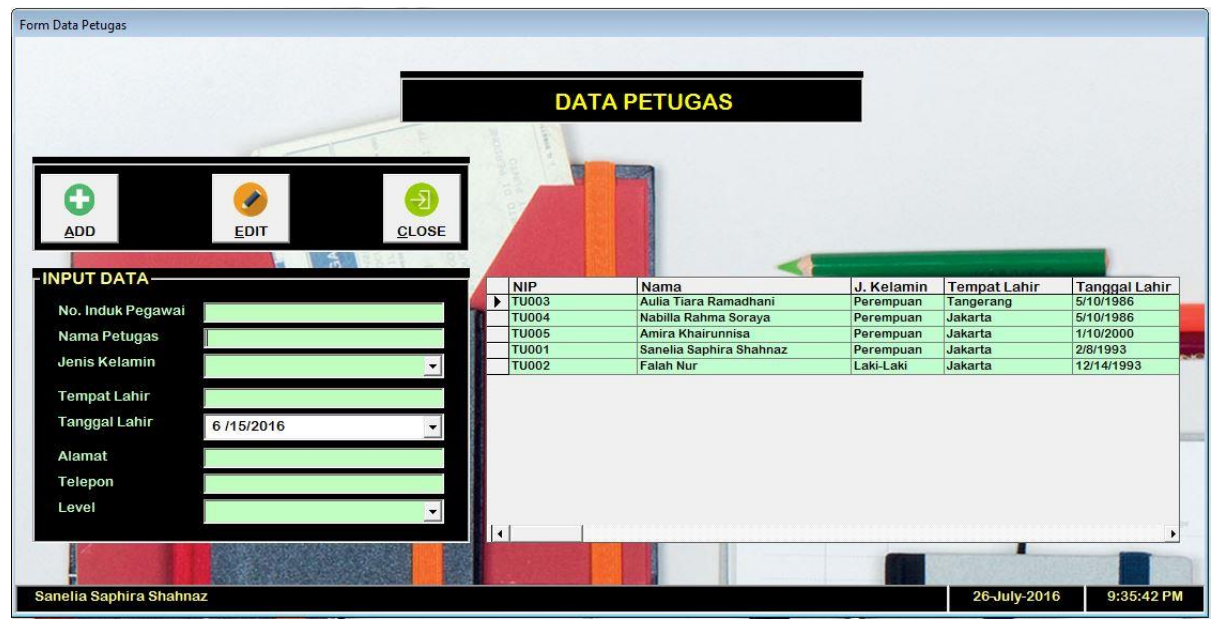

Gambar 4. Form Petugas

b. Form Data Siswa

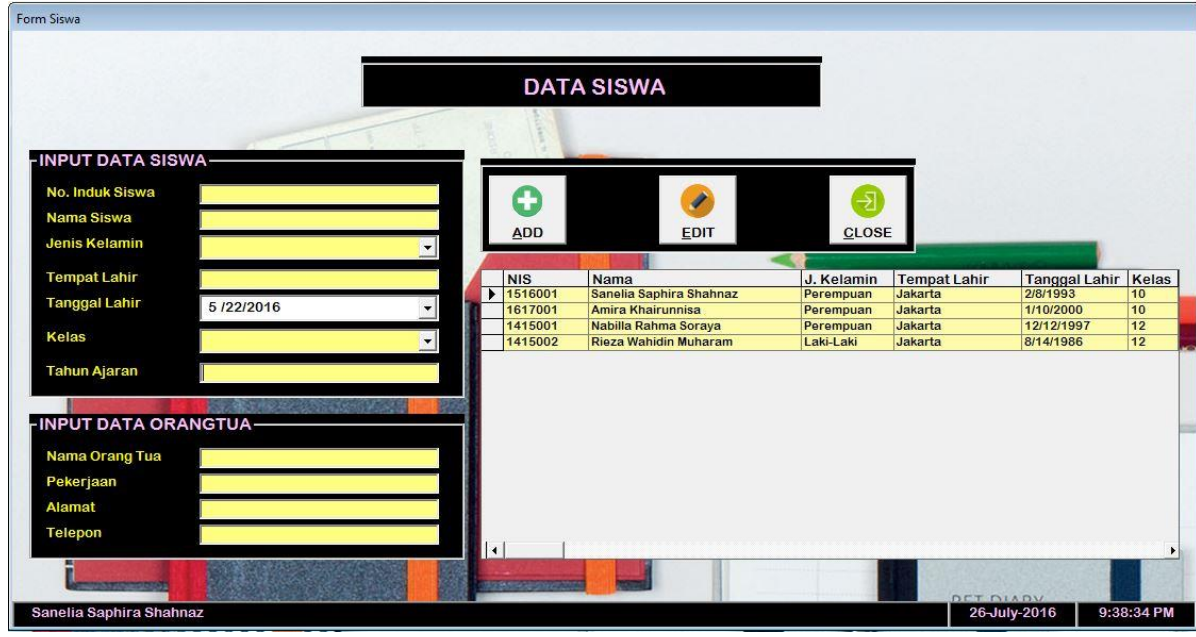

Gambar 5. Form Siswa

c. Form Data Donatur

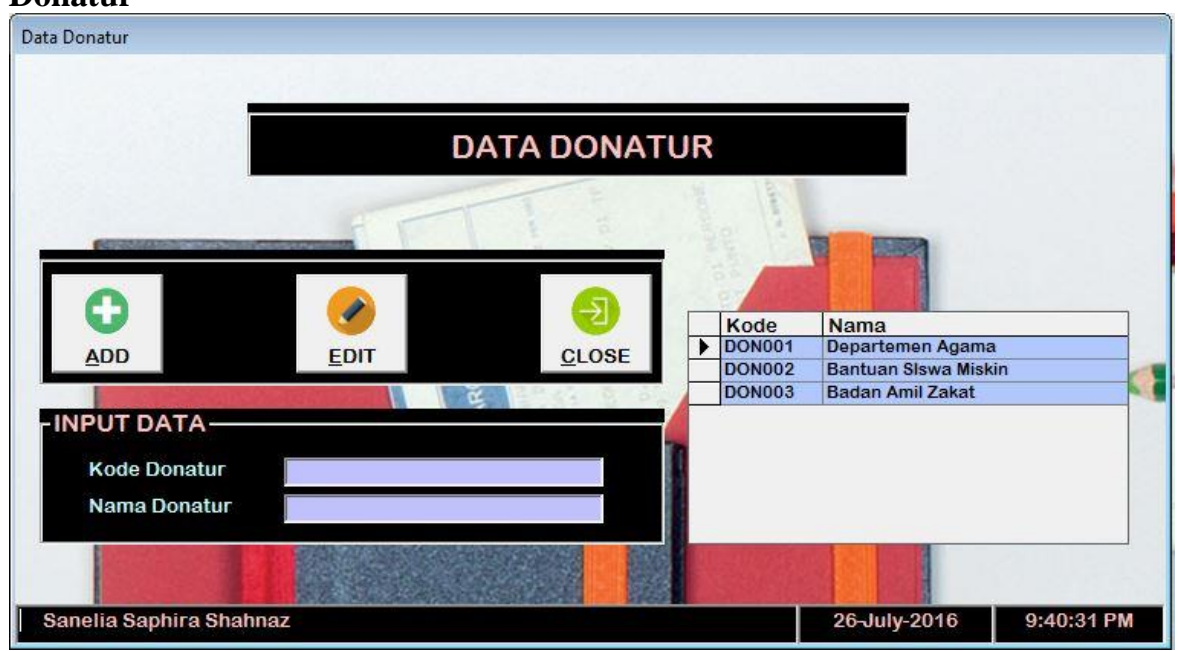

Gambar 6. Form Donatur 


\section{d. Form Data Beasiswa}

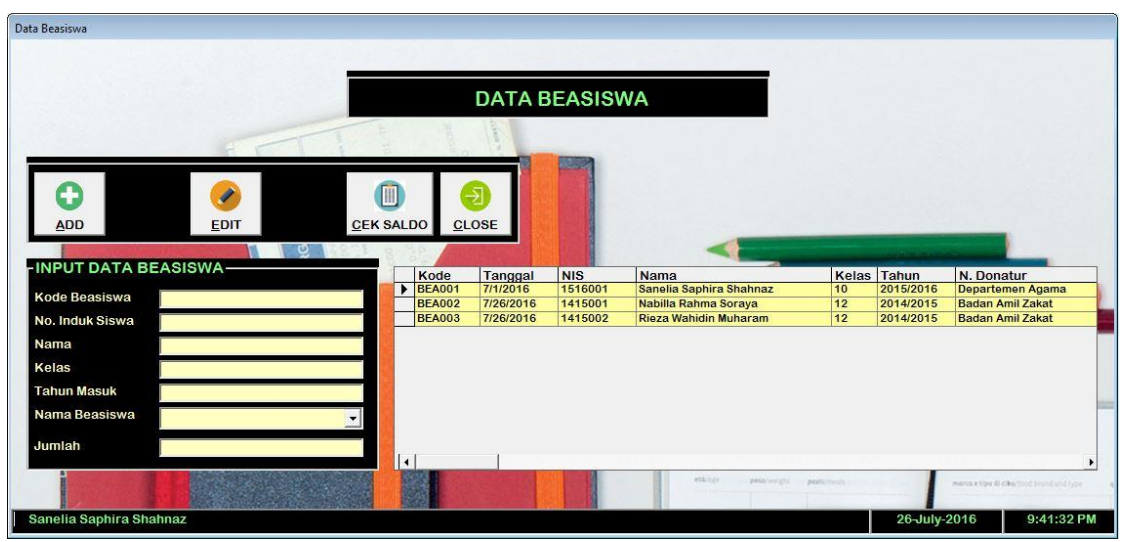

Gambar 7. Form Beasiswa

\section{e. Form Transaksi Pembayaran}

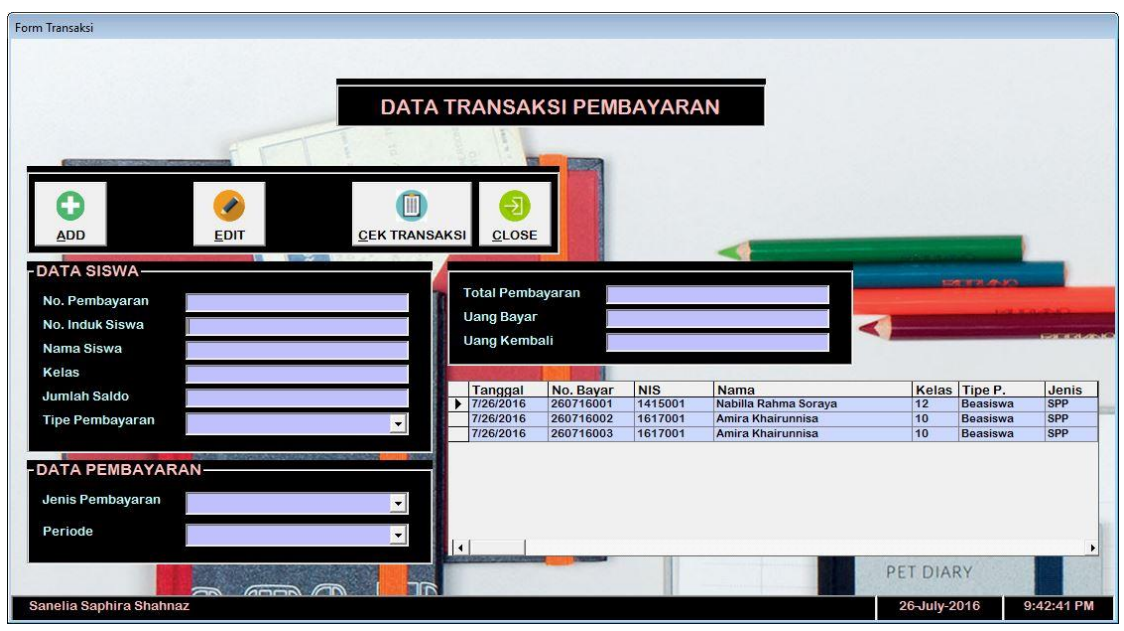

Gambar 8. Form Transaksi Pembayaran

g. Hasil Keluaran Transaksi Pembayaran SPP

\begin{tabular}{|c|c|c|c|}
\hline \multicolumn{4}{|c|}{ BUKTI PEMBAYARAN } \\
\hline No Transaksi & 010716001 & Tanggal & 7/1/2016 - \\
\hline NIS & 1516001 & & \\
\hline Nama & Sanelia Saphira & Kelas & 10 \\
\hline Pembayaran & Periode & \multicolumn{2}{|c|}{ Total Pembayaran } \\
\hline SPP & Juli & \multicolumn{2}{|c|}{80000} \\
\hline & Jenis Pembayaran & \multicolumn{2}{|c|}{ Beasiswa } \\
\hline & Uang Bayar & \multicolumn{2}{|c|}{80000} \\
\hline & Uang Kembali & \multicolumn{2}{|l|}{0} \\
\hline
\end{tabular}

Gambar 9. Output Bukti Pembayaran

\section{KESIMPULAN}

Semakin penting dan dibutuhkannya suatu aplikasi program yang cepat, tepat, dan akurat, maka akan mengharuskan suatu unit kerja untuk dapat memberikan informasi yang baik yaitu dengan menggunakan database yang terkomputerisasi. Dari uraian penjelasan, maka penulis mengambil kesimpulan bahwa: Pencatatan dari pengolahan data dan transaksi pembayaran masih dilakukan secara manual sehingga menyebabkan informasi yang tidak akurat. Belum adanya program/aplikasi khusus untuk mengolah data mengakibatkan pelayanan informasi mengenai data penjualan dan pembelian masih ditemukan banyak kesalahan. 
Bukti transaksi pada MA. Al-Marzukiyah ini masih tersimpan di lemari berkas sehingga memperbesar kemungkinan hilangnya berkas-berkas tersebut. Dengan adanya aplikasi ini, maka data tidak perlu disimpan dalam bentuk berkas lagi karena data sudah tersimpan di dalam database dan petugas cukup mencetak data-data tersebut pada saat dibutuhkan.

Sebagai bahan penutup dari laporan tugas akhir tentang perancangan program aplikasi berbasis visual basic, penulis memberikan saran yang mungkin dapat membantu agar perancangan aplikasi ini dapat bekerja secara optimal dan nantinya dapat diterapkan sebagai bahan pembenahan yang dapat meningkatkan efektifitas penggunanya.

\section{REFERENCES}

[1] Brady, M., dan John Loonam. 2010. Exploring the Use of Entity-Relationship Diagramming as a Technique to Support Grounded Theory Inquiry. Bradford: Emerald Group.

[2] Fathansyah. 2012. Basis Data. Bandung: Informatika.

[3] Ichwan, M. 2011. Pemrograman Basis Data Delphi 7 dan MySQL. Bandung: Informatika.

[4] Jubilee Enterprise. 2015. Pemrograman Visual Basic 6. Jakarta: PT Elex Media Komputindo.

[5] Kurniadi, Adi. 2011. Pemrograman Microsoft Visual Basic 6. Jakarta: PT Elex Media Komputindo.

[6] Kusumawati, Dewi. 2015. Basis Data dengan PostegreSQL. Yogyakarta: Graha Ilmu.

[7] Madcoms. 2014. Memaksimalkan Rumus dan Fungsi pada Microsoft Access 2013. Yogyakarta: Andi Offset.

[8] Mcleod, R., dan George P. Schell. 2011. Sistem Informasi Manajemen. Jakarta: Prentice Hall Inc.

[9] Mustakini, J. H. 2014. Analisis dan Desain Sistem Informasi: Pendekatan Terstruktur Teori dan Praktik Aplikasi Bisnis. Yogyakarta: Andi Offset.

[10] Pressman, R. S. 2010. Rekayasa Perangkat Lunak: Pendekatan Praktisi. Yogyakarta: Andi Offset.

[11] Sukamto, R. A., dan Muhammad Shalahuddin. 2011. Rekayasa Perangkat Lunak Terstruktur dan Berorientasi Objek. Bandung: Informatika.

[12] Wahana Komputer. 2014. 202 Tip dan Trik Microsoft Access 2013. Yogyakarta: Andi Offset. 